\title{
Poemas de Dimitris Daskalópulos
}

\section{Con el viento como red 2015}

\section{Efímera eternidad}

\author{
Al poder de los jardines \\ contrapropongo \\ las hojas caídas del otoño. \\ Al poder de los sonidos \\ murmuro las posibilidades \\ del silencio. \\ Al poder de la muerte \\ hablo de la renovación perpetua \\ de la vida. \\ El curvado día \\ me reprende cada mañana \\ con lo efímero de la oscuridad.
}




\section{Alejandría (1941 d. C.)}

Oleadas de gaviotas en la costa y despeinadas palmeras.

Centauro el otoño fuerza a la primavera.

Hasta donde llega la mirada viajan en las aguas bajas

sus figuras junto al mar:

trajes a rayas calvas prematuras,

relojes de plata de bolsillo - y emigración.

El fondo oculto sellado

con cerrojos que no se abren.

Los recuerdo paseando por la noche

viendo aquello que no se veía - sus anhelos.

Oscuros juegos y aroma de muerte

cuando amanecía el mañana en los relámpagos.

$Y$ aquel Anciano invisible

y presente, callado y locuaz

circulaba entre los relámpagos

y después bajaba incólume y telúrico

a retomar su puesto en las cosas cotidianas.

\section{Termópilas}

Por un verbo

por un imperativo

por aquel inútil verbo

por aquel arrogante $\beta \lambda \omega ́ \sigma \kappa \omega^{1}$

pleno de autonegación

fueron aniquiladas trecientas

trecientas orgullosas almas

en el Hades.

Muchísima sangre griega. ${ }^{2}$

1 Ir, venir, marcharse.

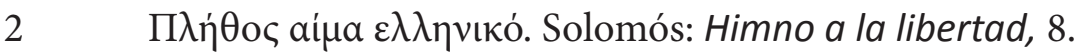




\section{Díptico Epitafio}

Repentinamente

comenzó a oscurecerse el día

en presencia del sol

y comenzó a silbar bajando

con fuerza de los montes en rápido vuelo

un tempranero viento invernal.

Los árboles del patio se inclinaban

golpeaban los abiertos postigos de las ventanas

todavía fieles al verano.

Un oculto temor se cobijó en los corazones-

Se santiguó murmuró

súplicas apropiadas para el momento.

No podía comprender

que descendía del cielo con la espada

para tomar su alma un Arcángel.

Noche en la ciudad noche en la región, hundido en la noche.

Desde entonces. 
II

He aquí cómo fueron las cosas.

De tardecita en el jardín del hospital

el débil fresco del crepúsculo trataba en vano

de competir con el calor del día.

No habían crecido cuerpo y mente

no sabías qué es el día siguiente.

Frente a ti prometedoras se extendían

los fértiles valles de la juventud y

un novel amor - moneda no circulante.

La ínfima nube delante de la luna

era la sombra que arrojaba la muerte

mientras se aproximaba vacilante-

Venía y se marchaba venía y se marchaba

con pasos silenciosos.

(La moneda falsa se demostró

los fértiles valles acabaron

en árida estepa.)

Cuando la visita terminaba

no dijiste el consagrado buenas noches

por no querer turbar su profundo sueño.

Sólo a la mañana siguiente comprendiste

que era el ensayo definitivo

para el sueño eterno.

Traducciones: Miguel Castillo Didier 